\title{
Manual Fetal Rotation
}

National Cancer Institute

\section{Source}

National Cancer Institute. Manual Fetal Rotation. NCI Thesaurus. Code C114133.

A procedure during labor in which the occiput is manually rotated from posterior to anterior. 